\title{
Three Step Interview as a Strategy on the Performance in Science of Grade 8 Students
}

\author{
GABRIELA C. GALCERAN \\ Student, College of Education and Social Sciences \\ Mindanao State University at Naawan \\ 9023 Naawan, Misamis Oriental \\ Philippines \\ BELLA C. MUGOT, MST \\ Faculty, College of Education and Social Sciences \\ Mindanao State University at Naawan \\ 9023 Naawan, Misamis Oriental \\ Philippines
}

\begin{abstract}
This study aimed to determine the effectiveness of Three step interview as a strategy on the performance in science of grade 8 students. Specifically this study aims to find out the significant difference on the pretest scores in science of the students when grouped to Three step interview as a strategy and lecture method; it finds out the significant difference on the posttest scores in science of the students when taught using Three step interview as a strategy and lecture method and; it finds out the significant difference on the pretest and posttest scores in science of the students when taught using Three step interview as a strategy and lecture method. The study used the true experimental design. T-test, percentage and paired t-test were used to analyse the data. The results revealed that there was no significant difference on the prestest scores in science of the students when grouped to Three step interview as a strategy and lecture method since the $t$-value which is -1.32 corresponds to the p-value of 0.191 and is greater than $p \leq 0.05$ level of significance. The analysis also revealed that there was a significant difference on the posttest scores in science when students were taught using Three step interview as a strategy and lecture method since the t-value which is 4.61 corresponds to the pvalue of $2.26 \times 10^{-5}$ is lesser than $p \leq 0.05$ level of significance. The paired t-test results revealed that for the Three step interview group, there was a significant difference on the pretest and posttest scores in science of grade 8 students since the t-value which is -13.76 corresponds to the p-value of $3.02 \times 10^{-14}$ is lesser than $p \leq 0.05$ level of significance. For the lecture method group, there was significant difference on the pretest and posttest scores in science of grade 8 students since the t-value which is -12.04 corresponds to the $p$-value of $8.33 \times 10^{-13}$ is lesser than $p \leq 0.05$ level of significance. The use of the Three step interview as a strategy in teaching science can greatly improve students' performance.
\end{abstract}

Keywords: Performance, Lecture Method, Strategy

\section{Introduction}

Three step interview as a cooperative learning is an educational approach to teaching and learning that involves group of students working together to solve a problem, complete a task, or create a product. Cooperative learning is based on the idea that learning is a naturally social act in which the participants talk among themselves. It is through the talk that learning occurs (Gerlach, 1994). This means more than simply paying attention or being on task it also involves actively participating in class by asking and answering questions, discussing content-related information with peers to complete the task. The three step interview is an effective way to encourage students to share their thinking, ask questions, and take notes. It work best in three students per group, but it can be modified for groups of four (Bennett etat., 2001).

In Three-step Interview technique, students not only learn and receive learning experience and knowledge from the teacher, but also learn from other students. In other words, they are more active and creative in joining the learning process. The three-step interview as strategy incorporates a blend of role-playing and discussion to facilitate student learning. The cooperative learning technique facilitates the development of skills such as active listening, note-taking and sharing information. The strategy comprises of Q\&A sessions and interviews, enhancing student interest and engagement, and in turn making learning more fun and enjoyable in the classroom (Coffey, 2010). 
Science is a systematic enterprise that builds and organizes knowledge in the form of testable explanations and predictions about the universe. Contemporary science is typically subdivided into the natural sciences which study the material world, the social sciences which study people and societies, and the formal sciences like mathematics. Some do not consider formal sciences to be true science as theories within these disciplines cannot be tested with physical observations, although others dispute this view. Disciplines which use science like engineering and medicine may also be considered to be applied sciences (Harper 2014).

\section{Methodology}

The study used a true experimental design, the randomized pre-test, post-test control group design. Two sections in grade 8 were used, with one group taught using Three Step Interview strategy and other group taught using lecture method. Random assignment was used to form the groupings. The performance in Science of the students was measured through pre-test and post-test in Science during the fourth quarter.

A letter of approval from the school principal was obtained upon entering the school premises. A letter of request was given to the biology teacher for the conduct of the study. The researcher then asked the biology teacher of the Grade 8 students about the topic in their science class for the implementation of the study. The pretest was conducted to the grade 8 sections Faith and Obedient. For the gathering of data, there was a random selection of the thirty (30) students from section Faith and thirty (30) students from section Obedient. After the retrieval of the pretest, the researcher started the implementation the Three step interview as strategy the in class.

Three step interview was implemented using the following steps: students were divided into groups of (6) six members. Each group was given a topic to be discussed. The three steps then were introduced, with 2-3 minutes being allocated for each step. Each member in the group assumes the role of interviewer, interviewee and reporter/note-taker; with each student having the opportunity to play each role. Each student were marked as A, B and C. The interview process was conducted in three steps: first step, the interviewer was student $\mathrm{A}$, the interviewee was student B, the reporter was student C. Second step, the interviewer was student C, the interviewee was student A, the reporter was student B. Third step, the interviewer was student $\mathrm{B}$, the interviewee was student $\mathrm{C}$, the reporter was student $\mathrm{A}$ and so on

After the implementation of the study, posttest was administered to determine the students' performance in biology. The researcher gathered and organizes the data and was analyse using T-test and paired t-test. The results of the statistical analysis were made as the basis of the concept development.

\section{Results and Discussion}

\section{Pretest score in science of the students when grouped to Three step interview as a strategy and lecture method}

Figure shows the percentage distribution of the pretest scores in science of grade 8 students when grouped to Three step interview group and lecture method group. It is shown that $100 \%$ or 30 out of 30 students got the score ranging from 0 to17, which means that students did not meet the expectation. None of the grade 8 students got the score ranging from 18 to 30 .

When grade 8 students were grouped to Three step interview as a strategy and lecture method $100 \%$ or 30 out of 30 of the students got the score ranging from 0 to17, none of them got the score ranging from 18 to 30, which means that 30 out of 30 students did not meet the expectation. According to Rosnani, et al., (2015) pretests from the first meeting were low. This was because the students do not have enough background knowledge about the topic. They were also still unfamiliar with some of the questions. According to Astuti, M. (2014) students find it difficult to understand the text because of many unfamiliar vocabularies and so they often used dictionary.

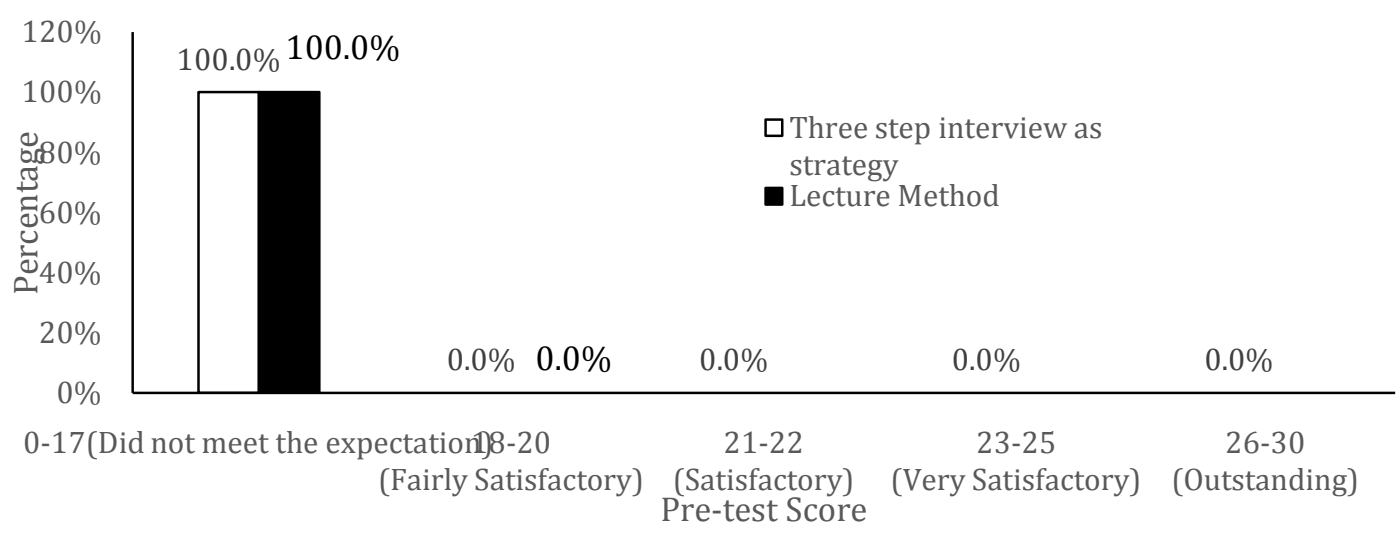




\section{Posttest score in science of the students when taught using Three step interview as a strategy and lecture method}

Figure shows the percentage distribution of the posttest scores in science of grade 8 students when taught using Three step interview as a strategy and lecture method. It is shown that $53.3 \%$ or 16 out 30 students got the score ranging from 0 to 17 , which means that students did not meet the expectation. $46.7 \%$ or 14 out 30 students got the score ranging from 18 to 20 , and none of them got the score ranging from 21 to 30 . For the lecture method group, $93.3 \%$ or 28 out 30 students got the score ranging from 0 to 17 which means that they did not meet the expectation. $6.7 \%$ or 2 out 30 students got the score ranging from 18 to 20, and none of them got the score ranging from 21 to 30 .

When students were taught using Three step interview as a strategy $53.3 \%$ or 16 out 30 of them got the score ranging from 0 to 17 which mean that students did not the expectation. $46.7 \%$ or 14 out 30 students got the score ranging from 18 to 20 , and none of them got the score ranging from 21 to 30. There was already improvement in their posttest scores when students were already taught using Three step interview as a strategy.

Coleman (1959) suggests that instead of encouraging competition in the academic setting, "which effectively impedes the process of education", schools should introduce a more collaborative approach to teaching. Students perceive that their success or failure is dependent upon their ability to work together as a group; students are likely to encourage each other to do whatever helps the group succeed. They are also more likely to help each other with the task at hand.

According to Johnson and Johnson's (1989), cooperative learning is doubtlessly a great way of learning. It is a great field of research and study as well. Cooperative learning encourages students to work in groups and teams. The core aim of this group or team is to achieve a specific task. Groups are created at beginning of the semester, for some specific semester activity, or for any other collaborative purpose. In this new method of learning, students learn much more than what they can learn in the typical mode of learning.

This signifies that cooperative learning specifically Three step interview has shown increase in student achievement, race relations, acceptance of special needs students, performance and self-esteem. When students were taught using lecture method $93.3 \%$ or 28 out 30 of them got the score ranging from 0 to 17 which means that they did not meet the expectation. $6.7 \%$ or 2 out 30 students got the score ranging from 18 to 20 , and none of them got the score ranging from 21 to 30. There was also improvement in their posttest score when students were taught using lecture method.

According to Farooq, (2012) science could be learned with the use of lecture method. Lecture method is the oldest teaching method applied in educational institution. This teaching method is one way channel communication of information. Students involve in this teaching method is just listen and sometimes pen down notes if necessary during the lecture. But students can learn best when they are truly engaged in what they are learning. We give pupils something to do, not something to learn; and the doing is of such a nature as to demand thinking. Rather than blaming cell phones, and other gadgets for absence of student commitment, teachers would improve to take a hard look at the instructional strategies they are using. There are alternative proven, engaging instructional strategies that avert distractions for students learning and which enhance joy and success in teaching and learning.

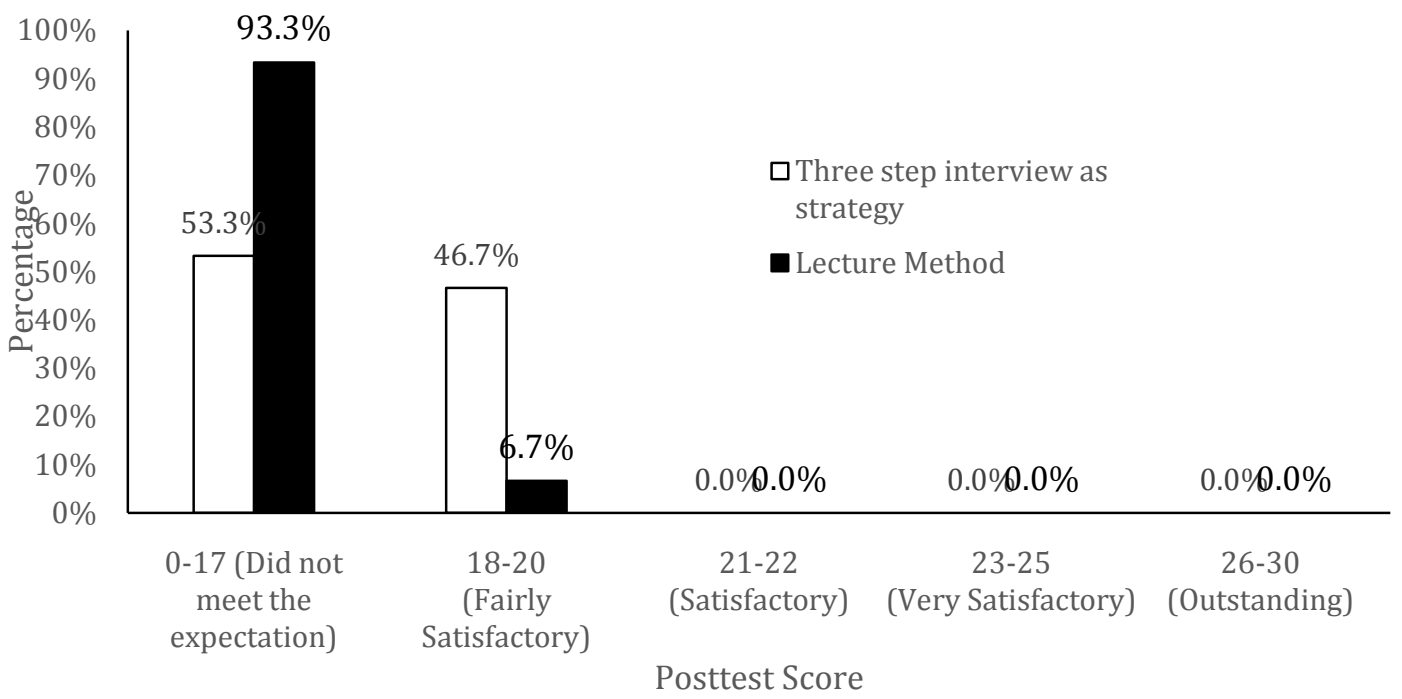

3. Difference on the pretest score in science of grade 8 students when grouped to three step interview as a strategy and lecture method 
Table 1 shows the difference on the pretest scores in science of grade 8 students when grouped to Three step interview as a strategy and lecture method. The analysis reveals that there is no significant difference on the pretest score since the $\mathrm{p}$-value which is 0.191 corresponds to the $\mathrm{t}$-value of -1.32 is greater than the $\mathrm{p} \leq 0.05$ level of significance. Therefore the null hypothesis $\left(\mathrm{H}_{01}\right)$ is not rejected.

T-Test result shows no significant difference on the students' pretest scores in science when grouped to Three step interview as a strategy and lecture method. It means that students' prior knowledge about the topic are more learn the same. Science in a broad sense existed before the modern era and in many historical civilizations. Modern science is distinct in its approach and successful in its results, so it now defines what science is in the strictest sense of the term. Science in its original sense was a word for a type of knowledge rather than a specialized word for the pursuit of such knowledge. In particular, it was the type of knowledge which people can communicate to each other and share. For example, knowledge about the working of natural things was gathered long before recorded history and led to the development of complex abstract thought. This is shown by the construction of complex calendars, techniques for making poisonous plants edible, public works at national scale, such which those which harnessed the floodplain of the Yangtse with reservoirs, dams, and dikes, and buildings such as the Pyramids. However, no consistent conscientious distinction was made between knowledge of such things, which are true in every community, and other types of communal knowledge, such as mythologies and legal systems (Lindberg, 2007).

Table 1. T-test results on the difference of the pre-test scores in Science of grade 8students when grouped to Three step interview as a strategy and lecture method

\begin{tabular}{|c|c|c|c|c|c|}
\hline Pre-test & mean & $\begin{array}{l}\text { mean } \\
\text { difference }\end{array}$ & $\mathrm{t}$-value & $\mathrm{p}$-value & remarks \\
\hline \multirow[t]{2}{*}{$\begin{array}{l}\text { Three step interview as a } \\
\text { strategy }\end{array}$} & 9.03 & & & & \\
\hline & & 1.00 & 1.32 & 0.191 & not significant \\
\hline Lecture Method & 8.03 & & & & \\
\hline
\end{tabular}

4. Difference on the posttest scores in science of grade 8 students when taught using Three step interview as a strategy and lecture method

Table shows the difference on the posttest scores in science of grade 8 students when taught using Three step interview as a strategy and lecture method. The analysis reveals that there is a significant difference in their posttest scores, in favor of Three step interview as a strategy, since the p-value which is $2.26 \times 10^{-5}$ corresponds to t-value of 4.61 is less than the $\mathrm{p} \geq 0.05$ level of significance. Therefore, the null hypothesis $\left(\mathrm{H}_{01}\right)$ is rejected.

Table 2. T-test results on the difference of the post-test scores in Science of grade 8students when taught using Three step interview as a strategy and lecture method

\begin{tabular}{lllllll}
\hline Posttest & & mean & $\begin{array}{l}\text { mean } \\
\text { difference }\end{array}$ & t-value & p-value & remarks \\
\hline $\begin{array}{l}\text { Three step interview as a } \\
\text { strategy }\end{array}$ & & 16.73 & & & & \\
& & 2.53 & 4.61 & $2.26 \times 10^{-5}$ & significant \\
Lecture Method & 14.20 & & & & \\
\hline With $p \geq 0.05$ level of significance & & & &
\end{tabular}

5. Difference on the pretest and posttest scores in science of grade 8 students when taught using Three step interview as a strategy and lecture method

Table 3 shows the difference on the pretest and posttest scores in science of grade 8 students when taught using Three step interview as a strategy and lecture method. Paired t-test analysis reveals that there is a significant difference on the pretest and posttest scores of the students when taught using Three step interview as a strategy, in favor of posttest, since the $t$-value is -13.76 and the $p$-value, which is $3.02 \times 10^{-14}$, is less than the $p \geq 0.05$ level of significance.

The analysis also reveals that there is a significant difference on the pretest and posttest scores of the students when taught using lecture method, in favor of posttest, since the t-value is -12.04 and the p-value, which is $8.33 \times 10^{-13}$, is less than the $\mathrm{p} \geq 0.05$ level of significance. Therefore the null hypothesis $\left(\mathrm{H}_{01}\right)$ is rejected.

T-Test result revealed a significant difference on the students' posttest scores in science when taught using Three step interview as a strategy and lecture method. 
Three Step Interview engage students in conversation for the purpose of analyzing and synthesizing new information. The Three Step Interview is a cooperative structure that helps students personalize their learning and listen to and appreciate the ideas and thinking of others. Active listening and paraphrasing by the interviewer develops understanding and empathy for the thinking of the interviewee (Lipton et al., 1998).

Table 3. Paired t-test results on the difference of the pre-test and posttest scores in science of grade 8 students when taught using Three step interview as a strategy and lecture method

\begin{tabular}{lccccc}
\hline & Mean & $\begin{array}{c}\text { Mean difference } \\
\text { Three step interview as strategy }\end{array}$ & P-value & Remarks \\
Pretest & 9.03 & & & \\
& & -7.70 & -13.76 & $3.02 \times 10^{-14}$ & significant \\
Posttest & 16.73 & & & \\
Pretest & 8.03 & Lecture method & & \\
& & & & & \\
Posttest & 14.20 & -6.17 & -12.04 & $8.33 \times 10^{-13}$ & significant \\
\hline With $p \geq 0.05$ level of significance & & & &
\end{tabular}

\section{Summary and Conclusion}

1. For the students' pretest score in science when grouped to Three step interview as a strategy and lecture method, $100 \%$ of the students got the score ranging from 0 to 17 which means that students did not meet the expectation, none of them got the score ranging from 18 to 30, which means that 30 out of 30 did not meet the expectation.

2. For the students' postest score in science when taught using Three step interview as a strategy, $53.3 \%$ got the score ranging from 0 to 17 which means that students did not the expectation, $46.7 \%$ students got the score ranging from 18 to 20 , and none of them got the score ranging from 21 to 30 .

3. Based on the students' posttest score in science when taught using lecture method, $93.3 \%$ got the score ranging from 0 to $17,6.7 \%$ got the score ranging from 18 to 20 , and none of them got the score ranging from 21 to 30 .

4. There was no significant difference on the students' pretest scores in science when grouped to Three step interview as a strategy and lecture Method.

5. There was a significant difference on the students' posttest scores in science when taught using Three step interview as a strategy and lecture method.

6. Paired t-test results revealed significant difference on the students' pretest and posttest scores in science when taught using Three step interview as a strategy and there was a significant difference on the students' pretest and posttest scores in science when taught using lecture method.

7. This study concluded that Three step interview as a strategy can improve the students' performance in science.

\section{Summary and Conclusion}

1. This study determined the effectiveness of the Three step interview as a strategy on the performance in science of grade 8 students. Specifically, this study aimed to determine the pretest score in science of the students when grouped to Three step interview as a strategy and lecture method; determine the posttest score in science of the students when taught using Three step interview as a strategy and lecture method; find out the significant difference on the pretest scores in science of the students when taught using Three step interview as a strategy and lecture method; find out the significant difference on the posttest scores in science of the students when grouped to Three step interview as a strategy and lecture method; find out the significant difference on the pretest and posttest scores in science of the students when taught using Three step interview as a strategy and lecture method. The study used a true experimental design, the randomized pre-test, post-test control group design. This study was conducted to sixty (60) grade 8 students of Manticao National High School, Manticao, Misamis Oriental, S.Y. 2017-2018. Both the two groups were given pretest before the conduct of the study and posttest after the implementation of the study. The study made use of percentage, T-Test and paired t-test to analyze the results.

2. For the students' pretest score in science when grouped to Three step interview as a strategy and lecture method, $100 \%$ of the students got the score ranging from 0 to 17 which means that students did not meet the expectation, none of them got the score ranging from 18 to 30 , which means that 30 out of 30 did not meet the expectation. 
3. For the students' postest score in science when taught using Three step interview as a strategy, $53.3 \%$ got the score ranging from 0 to 17 which means that students did not the expectation, $46.7 \%$ students got the score ranging from 18 to 20 , and none of them got the score ranging from 21 to 30 .

4. Based on the students' posttest score in science when taught using lecture method, $93.3 \%$ got the score ranging from 0 to $17,6.7 \%$ got the score ranging from 18 to 20 , and none of them got the score ranging from 21 to 30 .

5. There was no significant difference on the students' pretest scores in science when grouped to Three step interview as a strategy and lecture Method.

6. There was a significant difference on the students' posttest scores in science when taught using Three step interview as a strategy and lecture method.

7. Paired t-test results revealed significant difference on the students' pretest and posttest scores in science when taught using Three step interview as a strategy and there was a significant difference on the students' pretest and posttest scores in science when taught using lecture method.

8. This study concluded that Three step interview as a strategy can improve the students' performance in science.

\section{Implications and Recommendation}

1. The results of this study showed that Three step interview as a strategy can improve students' performance when used in teaching science.

2. The teacher must arrange proper group formation to avoid noise and instead encourage the students to speak. The teacher should artistically use certain method in teaching, especially in the science class, in order to engage the students to be more active during the learning process.

3. For the future researchers who want to conduct similar study, it should be conducted in at least 3 trials in order to have better results.

4. It is recommended that this strategy should be used in other year level. Adjustment should be made with the questions to be used. The questions should not be too easy or too difficult. Questions must be appropriate to the students' mental ability and prior knowledge.

\section{References}

Armstrong, 1994. Performance. https://www.businessdictionary.com/definition/performance.html

Astuti, M. 2014. “The Effectiveness of Three step interview On Students' Reading Ability". SyarifHidayatullah State Islamic University. Jakarta.

Balentine J. 2007. Parts and function of the digestive system.

https://www.medicinenet.com/the_digestion_process_organs_and_functions/article.htm

Baron, 2005. Performance. https://www.businessdictionary.com/definition/performance.html

Bennett, B. and Carol R. (2001).Beyond Monet: The Artful Science of Instructional Integration.

Toronto, Ontario: Bilocation, 167-168.

Castro J. 2013. 11 Facts about digestive system. https://www.livescience.com/40187-digestive-system-surprisingfacts.html

Chin, C. et.al 2000. Learning in Science: A Comparison of Deep and Surface Approaches, Journal of Research in Science Teaching, 37, 109-138

COFFEY. 2010. https://teaching-strategies.wikispaces.com/3-Step+Interview

Dewey, J. 1916. Democracy and Education: An Introduction to the Philosophy of Education. New York, Free Press.

Dewey, J. 1916. Democracy and education. New York, Macmillan.

Ewens. 2000. Classroom participation. https://pamirtimes.net/2011/09/12/opinon-effects-of- student-participation-in-aclassroom/

Farooq, U. 2012. Definition of lecture method of teaching. https://www.studylecturenotes.com/socialscience/education/382-lecture-method-of-teaching-definition-advantages-and-disadvantages

Gerlach. 1994. What is cooperative learning.http://archive.wceruw.org/cl1/cl/moreinfo/MI2A.htm

Greenwood, C. R., et.al. 2001.The research to practice gap in special education. Teacher Education and Special Education, 24(4), 276-289

Johnson, R., et.al. 1989.Effects of cooperative, competitive, and individualistic goal structures on computer-assisted instruction. Journal of Educational Psychology, 77, 668-677.

Johnson, D.et.al. 1999.Cooperation and competition. Edina, interaction Book Company.

Lipton, L., \& Wellman, B. 1998. Patterns and practices in the learning-focused classroom. Guilford, Vermont: Pathways Publishing. 
Maheady, L. et.al 2006. The effects of numbered heads together with and without an incentive package on the science test performance of a diverse group of sixth graders. Journal of behavioral education, 15(1), 25-39.

Piaget, J. 1970. Science of education and the psychology of the child. New York, Viking Press.

Piaget, J. 1985. Equilibration of cognitive structures. Chicago, University of Chicago Press.

Rosnani, S. et.al 2015. A Study on Improving Students' Reading Comprehension Using the Numbered Heads Together Technique. Syiah Kuala University, Banda Aceh, INDONESIA

Skolverket, B.I. 2009. BIO. Biology Swedish National Agency for Education http://334.edb.hkedcity.net/doc/eng/framework1/bio.pdf. Retrieved on October 23,2016

Slavin, R.1986. Using student team learning. Baltimore, MD: Center for Social Organization of Schools, Johns Hopkins University.

Slavin, R. 1988. Educational psychology theory into practice (2nd Ed.). Englewood Cliffs, Prentice Hall.

Svihus B. 2014. The Journal of Applied Poultry Research, Volume 23, Issue 2, 1 June 2014, $\quad$ Pages 306314,https://doi.org/10.3382/japr.2014-00937

Torrington, 1995. https://www.ukessays.com/essays/business/definitions-of-performance- management-businessessay.php

Weiss, 1997. https://www.ukessays.com/essays/business/definitions-of-performance-management-business-essay.php 